\title{
Terörizm ve Medya Çerçevelemesi Üzerine Bir Analiz: YPJ Örneği
}

\author{
Oğuzhan Yanarışı*
}

\section{Öz}

2011 yılından bu yana devam eden Suriye iç Savaşı, pek çok bölgesel ve küresel aktörün müdahalesine maruz kalmıştır. Bazı terör örgütleri, bu dönemde ortaya çıkan otorite boşluğu ve kaos ortamından faydalanarak Suriye'de etkin hale gelmiş ve önemli toprak kazanımları elde etmiştir. Bunların başında PKK/YPG terör örgütü gelmektedir. YPG ve özellikle de onun kadınlardan oluşan birimi YPJ, ana akım Batı medyasında epey olumlu bir şekilde tasvir edilmiştir. YPJ bir taraftan terör örgütü DEAŞ’ın antitezi olarak yüceltilmiş; diğer taraftan ütopik bir feminizm kurgusu üzerinden kahramanlaştırılmıştır. Olumlu ve övgü dolu medya çerçevelemesi Batılı aktörlerin YPJ'yle ve onun ana çatısını oluşturan YPG terör örgütüyle iş birliği yapmasını meşrulaştırmıştır. Bu medya çerçevelemesi, aynı zamanda Batı toplumlarının farklı kesimlerinin değişen derecelerde radikalleşmesinde rol oynamıştır. Bazı kesimler sempatizan haline gelmiş; bazıları siyasi ve mali olarak destek vermiş; bazıları ise YPJ'ye gönüllü militan olarak katılacak kadar ileri gidebilmiştir.

Anahtar Kelimeler: YPJ, Medya Çerçevelemesi, YPG, Terörizm ve Medya Iliş̧kisi, Terörizm, Uluslararası Güvenlik.

\section{An Analysis on Terrorism and Media Framing: the Case of YPJ}

\section{Abstract}

The Syrian Civil War, which has been going on since 2011, has been subject to interventions of many regional and global actors. Some terrorist organizations took advantage of the authority vacuum and chaos environment that emerged during this period and became active in Syria and achieved significant land gains. PKK/ YPG terrorist organization comes first among these. The YPG, and especially its women's unit, the YPJ, have been portrayed in a positive way by the mainstream Western media. On the one hand, the YPJ has been glorified as the antithesis of the terrorist organization DAESH. On the other hand, it has been heroized over a utopian feminism fiction. The positive and laudatory media framing has legitimized the cooperation of Western actors with the YPJ and its main body, the YPG terrorist organization. This media framing has also played a role in radicalisation of different segments of Western societies to varying degrees. Some segments have become sympathizers; some of them have given political and financial support; while some have gone so far as to join the YPJ as volunteer militants.

Keywords: YPJ, Media Framing, YPG, Terrorism and Media Relationship, Terrorism, International Security.

*Dr. Öğr. Üyesi | Polis Akademisi, Güvenlik Bilimleri Enstitüsü, Uluslararası Güvenlik Anabilim Dalı yanarisik@gmail.com | ORCID:0000-0003-3442-4779 | DOI: 10.36484/liberal.938217 Liberal Düşünce Dergisi, Yıl: 26, Sayı: 102, Bahar 2021, ss.241-256. Gönderim Tarihi: 17 Mayıs 2021 | Kabul Tarihi: 15 Haziran 2021 


\section{Giriş}

2011 yılından bu yana devam eden Suriye İç Savaşı, süreç içerisinde pek çok bölgesel ve küresel aktörün müdahalesine maruz kalmıştır. Bazı terör örgütleri de bu dönemde ortaya çıkan otorite boşluğu ve kaos ortamından faydalanarak Suriye'de etkin hale gelmiş ve önemli toprak kazanımları elde etmiştir. Bunların başında PKK/YPG terör örgütü gelmektedir. YPG (Yekîneyên Parastina Gel / Halk Koruma Birlikleri), Amerika Birleşik Devletleri, Avrupa Birliği, Birleşmiş Milletler ve Türkiye tarafından terörist grup olarak tanımlanan PKK’nın (Partîya Karkerên Kurdistanê / Kürdistan İşçi Partisi) Suriye kolu olan neo-Marksist bir gruptur. 2013 yılında kurulan ve ismi "Kadın Koruma Birimleri” anlamına gelen YPJ (Yekîneyên Parastina Jin) ise YPG'nin yalnızca kadınlardan oluşan birimidir. Ana sloganı "Kadın, Yaşam, Özgürlük” olan grubun 10.000 ila 20.000 üyesi olduğu tahmin edilmektedir (Benedetta, 2017).

YPJ, kendi ifadesiyle "feminist liberter sosyalist" felsefesini PKK terör örgütünün ana ideoloğu ve kurucusu olan Abdullah Öcalan’ın yazılarına ve görüşlerine dayandırmaktadır. Öcalan'ın “Kürt halkının özgürlüğü ayrılmaz bir şekilde kadınların özgürlüğüne bağlıdır” sözünü kendisine ilke edindiğini öne sürmektedir (Tank, 2017: 419-420). PKK ele başı Öcalan ile bağlarını hiçbir şekilde gizlemeye çalışmamaktadır. Kıyafetlerinden bayraklarına kadar pek çok sembolünde Öcalan'ın resmini kullanmaktadır. Örneğin, DEAŞ terör örgütünün kontrolü altındaki Suriye'nin Rakka şehrini kontrol altına aldıktan sonra devasa bir Öcalan posterinin önünde poz verip, “Rakka zaferini Öcalan’a adıyoruz" açıklamasını yapmıştır (Reuters, 2017).

ABD’li yetkililer uzun süre YPG ile kanlı bir geçmişe sahip olan PKK arasında organik ilişki olduğu gerçeğini inkâr etmiş ve kendisinin terör örgütü olarak tanıdığı bir gruba destek veriyor olma durumunu örtmeye çalışmıştır. Fakat PKK ve YPG yetkililerinin bu ilişkiyi saklamaya çalışmadan ortak sembolleri ve söylemleri kullanmaları, YPG yöneticilerinin çoğunun PKK geçmişinden gelmesi, iki grubun sahada iç içe hareket etmesi gibi sebeplerle bu inkâr sürdürülemez hale gelmiştir. Bütün bu duruma rağmen, YPG ve özellikle de YPJ, ana akım Batı medyasında gayet olumlu bir şekilde tasvir edilegelmiştir.

YPJ bir taraftan terör örgütü DEAŞ’ın antitezi olarak yüceltilmiş; diğer taraftan ütopik bir feminizm kurgusu üzerinden kahramanlaştırılmıştır. Olumlu ve övgü dolu medya çerçevelemesi Batılı aktörlerin YPJ'yle ve onun ana çatısını oluşturan YPG terör örgütüyle iş birliği yapmasını meşrulaştırmıştır. Bu medya çerçevelemesi, aynı zamanda Batı toplumlarının farklı kesimlerinin 
değişen derecelerde radikalleşmesinde rol oynamıştır. Bazı kesimler sempatizan haline gelmiş; bazıları örgüte siyasi ve mali olarak destek vermiş; bazıları ise YPJ'ye gönüllü militan olarak katılacak kadar ileri gidebilmiştir.

Bu makalede öncelikle medya ve terörizm arasındaki simbiyotik ilişkiden bahsedilmekte; ardından medya çerçevelemesi kavramı üzerinde durulmaktadır. Daha sonra YPJ'nin ana akım Batı medyasındaki çerçevelemesi analiz edilmektedir. Bu kapsamda, ana akım İngilizce Batı medyasındaki ilgili haber metinlerinden, ulusal ve uluslararası kurumların raporlarından ve ilgili akademik literatürden istifade edilmektedir.

\section{Medya ve Terörizm İliş̧isi}

Literatürde genel itibariyle terörizm ile medya arasında neredeyse simbiyotik bir ilişki olduğu görüşü yaygın olarak kabul görmektedir. Bu ilişkide terörizm medyaya haber ürününün satışına yardımcı olan heyecan verici ve şiddet içeren hikayeler sağlamaktadır. Medya ise karşılık olarak terörist gruplara mesajlarını yayma ve halk arasında korku oluşturma araçları sunmaktadır. Terörizm medyayı kamuoyunun dikkatini çekmek, bu yolla kendi davasına sempati kazandırmak ve halkta endişe ve korkuyu yaymak maksatlarıyla kullanmaktadır (Spencer, 2012: 6-8). Bu karşılıklı çıkara dayalı yakın ilişki sebebiyle, bazı gözlemciler medya organlarını terörizmin "suç ortaklar1” (Schmid 1989: 540) ve terörizmin "en iyi dostları” (Hoffman 2006: 183) olarak tarif etmişlerdir. İngiltere Eski Başbakanı Margaret Thatcher, medyayı terörizme "reklam oksijeni” sağlamakla eleştirmiştir (Thatcher, 1985).

Medyanın terörist eylemleri yayınlarında işlemesinin önüne geçerek sansür uygulamanın iki önemli sakıncası bulunmaktadır. Birincisi, bu yaklaşımın halkın haber alma hürriyetini tehdit etme potansiyeli taşımasıdır. İnsan Hakları Evrensel Beyannamesi'nde de ifade edildiği üzere, "Herkesin kanaat ve ifade özgürlüğüne hakkı vardır; bu hak, müdahale olmaksızın kanaat taşıma ve herhangi bir yoldan ve ülke sınırlarını gözetmeksizin bilgi ve fikirlere ulaşmaya çalışma, onları edinme ve yayma serbestliğini de kapsamaktadır" (Birleşmiş Milletler, 1948).

Fakat, Avrupa İnsan Hakları Sözleşmesi'nin 10. maddesinde de ifade edildiği üzere, "haber ve görüş alma ve de verme" hürriyeti sınırsız değildir:

“Görev ve sorumluluklar da yükleyen bu özgürlüklerin kullanılması, yasayla öngörülen ve demokratik bir toplumda ulusal güvenliğin, toprak bütünlüğünün veya kamu güvenliğinin korunması, kamu düzeninin sağlanması ve suç işlenmesinin önlenmesi, sağlığın veya ahlakın, başkalarının şöhret ve haklarının korunması, gizli bilgilerin yayılmasının önlenmesi veya yargı erkinin yetki ve tarafsızlığının güvence altına 
alınması için gerekli olan bazı formaliteler, koşullara, sınırlamalara veya yaptırımlara tabi tutulabilir" (Avrupa Komisyonu, 1950).

Dolayısıyla, bir terör örgütünü açıkça desteklemenin, yüceltmenin ve böylelikle şiddeti teşvik etmenin basın hürriyeti veya ifade hürriyeti kapsamında değerlendirilemeyeceği tartışma götürmez bir durumdur. Margaret Thatcher'in da vurguladığı üzere, liberal demokrasilerde her ne kadar medyaya sansür uygulanması savunulamazsa da medya organlarının terörle ilgili yayınlarında kendileri için gönüllü olarak davranış kuralları belirlemeleri hayati bir ihtiyaçtır. Ayrıca, "medyanın söyledikleri veya gösterdikleriyle teröristlerin moralini yükseltecek veya teröristlerin amacına hizmet edecek şekilde hareket etmemesini” beklemek kaçınılmazdır (Thatcher, 1985).

İkincisi, halkın erişimine açık kitle iletişim araçlarının çeşitliliği, böylesi bir sansürü tam anlamda uygulamayı pratik anlamda imkânsız hale getirmektedir (Spencer, 2012: 13). İnsanlar günümüzde sansür sebebiyle ulaşamadiğ1 bilgiye teknolojinin sunduğu fırsatlar sayesinde internet ve sosyal medya gibi farklı mecralardan erişebilmektedir. Editöryal düzenlemenin çok daha az olduğu veya hiç olmadığı bu platformlarda teröristlerin söylem üstünlüğü çok daha güçlü olabilmektedir.

Liberal demokratik toplumlarda medyanın terör ile ilgili konularda yayın yapmasının önüne geçmek mümkün olmadığına göre, ne şekilde yayın yapması gerektiğine dair tartı̧̧malar devam etmektedir. Terörizmle ilişkili yayınlarda kullanılan medya çerçevelemesinin önemli olduğu aşikardır. Çünkü medya kamuoyunun görüşlerinin ve tehdit algılamalarının şekillenmesinde çok önemli bir rol oynamaktadır (Woods, 2007: 15-16). Bu kapsamda, medya çerçevelemesi kavramına yakından bakmakta fayda bulunmaktadır.

\section{Medya Çerçevelemesi (Media Framing)}

1970’lerin sonlarından itibaren medyada haber üretimi, içeriği ve organizasyonuna yönelik ilgi hızla artmıştır (van Dijk, 1985: 70). Medya çerçevelemesi kavramı, geleneksel tartışmalardaki objektif olma veya önyargılı olma karşıtlığına alternatif üreten bir kavram olarak son dönemde oldukça popüler hale gelmiştir. James W. Tankard'ın ifadesiyle, öncelikle komplike bir mefhum olarak 'olumlu' veya 'olumsuz' kavramlarının ötesine geçmektedir. Medya çerçevelemesi, ilgili medya organına belirli bir meseleyle alakalı durumu tanımlama, sorunları belirleme ve tartışmanın koşullarını tayin etme imkânı tanımaktadır. Hikâyeyi sunuş biçimi, aslında o hikayeyle ilgili bir tarafın alternatifleri karşısında öncelenmesini beraberinde getirmektedir. Kendi çerçevesini kabul ettiren taraf, büyük bir avantaj sağlamaktadır. 
Medya çerçevelemesi, izleyici, dinleyici, okuyucu ve takipçi üzerinde güçlü etkiler bırakmaktadır. Bunu da çoğu zaman onlara fark ettirmeden yapmaktadır (Tankard, 2001: 96-97). Teun A. van Dijk'ın deyişiyle, medyanın gücü genel anlamda zihinleri kontrol etme ve böylece hareketleri etkilemeyi de kapsamaktadır. Bu nedenle, medyayla ilgili çalışmalar meselenin algı ve temsil boyutunu da içermelidir (van Dijk, 1995-b: 31).

Medya çerçevelemesi, olayların ve meselelerin özellikle medya tarafından organize edilme ve anlamlandırılma şeklini ifade etmektedir. Çerçeveleme analizleri, medyanın siyasi yaşamdaki rolünü anlamada özellikle yararlı olmaktadır (Reese, 2001: 7). Robert Entman'ın ifadesiyle, çerçeveleme algılanan bir gerçekliğin bazı yönlerini seçerek ön plana çıkarıp, iletişim metninde daha belirgin hale getirmektir. Böylelikle belirli bir problem tanımını, nedensel yorumu veya ahlaki değerlendirmeyi alternatiflerinin önüne çıkarmaktır (Entman, 1993: 52). Bir başka deyişle, çerçeveleme bir yayını yaparken haberin bazı unsurlarını seçme, bazılarını vurgulama, bazılarını çıkarma ve bazılarını detaylandırma yoluyla olaya bir bağlam sağlama ve meselenin ne olduğunu belirlemedir (Tankard, Hendrickson, Silberman, Bliss ve Ghanem, 1991: 11). Yani aslında hikâyeyi anlatan aktör, hikâyenin de ne olduğuna dair çok belirleyici bir rol oynamaktadır.

Teun A. van Dijk'ın vurguladığı üzere, medya tarafından uygulanan zihin kontrolü, medya kullanıcıları bu tür bir kontrolün doğasını veya sonuçlarını anlamadıklarında daha etkili olmaktadır. Ayrıca haberleri doğru olarak kabul ettikleri, habercilerin görüşlerini meşru gördükleri oranda, bu kontrolün düzeyi artmaktadır. Bu nedenle, kitle iletişim araçlarının kontrolü, çağdaş bilgi toplumlarında toplumsal gücü elinde bulundurmanın en önemli koşullarından biridir. Güçlü sosyal aktörler ve medya elitleri, yayınlardaki zamanı ve yeri, katılımcıları, izleyicileri, gündemleri, konuları, dil seçimini, üslubu ve diğer birçok faktörü belirleyerek medya söylemini kontrol edebilmektedir. (van Dijk, 1995-a: 11-12). Bazı medya organlarının sık sık kullandığı manipülatif söylem, olumsuz eylemlerin faillerinin kimliğini gizleyebilmekte, karartabilmekte veya belirsiz hale getirebilmektedir. Bu medya organları benzer şekilde, olumsuz fiiller ve olayları gizlemek için aktif çaba sarf edebilmektedir (van Dijk, 2017: 207).

Üzerinde geniş mutabakat olduğu sanılan olaylar da dahil olmak üzere her vakanın birçok alternatif çerçeveleme şekli bulunmaktadır. Örneğin, 11 Eylül 2001 terör saldırılarını gelişmiş iletişim teknolojilerinin de yardımıyla milyarlarca insan gerçek zamanlı olarak takip edebilmiştir. Ancak günün sonunda herkesin olay hakkında anlatacak kendisine özgü hikâyesi olmuştur. 
11 Eylül saldırısının herhangi bir değer içermeyen yalın açıklamasında muhtemelen şu ifade geçecektir: “11 Eylül 2001'de birkaç kişinin kontrol altına aldığı yolcu uçaklarından ikisi New York’ta iki yüksek binaya çarptı; biri de Washington'da başka bir binaya çarptı." Bu cümleye yapılacak herhangi bir ekleme, büyük olasılıkla hikâye anlatıcısının fikirlerinden, değerlerinden ve algılarından etkilenecek ve inşa edilmiş bir entelektüel arka planı yansıtacaktır.

Böyle bir hikâyenin olası bir versiyonunda bu cümle şu şekilde olabilecektir: “İnsanlığın kara günü olan 11 Eylül 2001'de birkaç Ortadoğulu radikal İslamcı teröristin kaçırdığı iki uçak ABD’nin ekonomik gücünü temsil eden Dünya Ticaret Merkezi kulelerine ve bir uçak da Amerikan askeri gücünü temsil eden Pentagon'a çarptı." Öte yandan, başka bir olası hikâyedeki cümle şu şekildedir: "11 Eylül 2001'de, kafirlere karşı cihat eden bir grup kahraman, ele geçirdiği uçaklardan ikisini Batı emperyalizminin ve sömürüsünün sembolü olan Dünya Ticaret Merkezi'ne ve birini tüm dünyadaki Amerikan zulmünün merkezi olan Pentagon'a çarptırdılar." O günle ilgili sınırsız sayıda alternatif anlatım şekli bulmak mümkündür. Bunların büyük bir kısmı da yukarıda verilen örnek anlatımlardan daha az duygusal ve daha az ideolojik olacaktır. Fakat günün sonunda aktörlerin maruz kaldıkları medya çerçevesi o aktörlerin olayın ardından izlediği politikaları şekillendirmiştir (Yanarışık, 2015: 80-82).

\section{Savaş Suçları İşleyen YPJ}

Uluslararası Ceza Mahkemesi'nin kuruluş statüsü olan Roma Statüsü'nde açık olarak ifade edildiği üzere, on beş yaşın altındaki çocukları silahlı çatışmalara aktif olarak katılmak için kullanmak bir savaş suçudur (Birleşmiş Milletler, 1998). Ayrıca, BM Çocuk Haklarına Dair Sözleşme’ye Ek Çocukların Silahlı Çatışmalara Dâhil Olmaları Konusundaki İhtiyari Protokol'ünde de vurgulandığı üzere, "silahlı gruplar, hiçbir koşul altında, muhasamatta 18 yaşın altındaki şahısları silahaltına almamalı ve kullanmamalıdır.” Çocukların özellikle silahlı çatışmalar esnasında tam anlamıyla korunmaları vazgeçilmez bir gerekliliktir (Birleşmiş Milletler, 2000: 3-5). Buna rağmen, YPJ açık bir şekilde çocukları militan olarak devşirmekte ve onların görsellerini paylaşmaktan çekinmemektedir.

Hatta ABD Merkez Kuvvetler Komutanlığı öncülüğünde bu konuda medya faaliyetleri yürütülmektedir. Örneğin, komutanlığın halen yayında olan bir Twitter mesajında çocuk yaşta oldukları açıkça görülen kızların fotoğrafları “Savaşa hazırlar. Yoğun istek üzerine Suriye'deki IŞİ̇ karşıtı operasyonda görev alan dişi savaşçıların fotoğraflarını paylaşıyoruz” mesajıyla servis edilmiştir (U.S. Central Command, 2014). Türkiye’nin Kuzey Suriye'deki askeri 
operasyonu esnasında etkisiz hale getirilen YPG üyelerinin kameralarından elde edilen görüntüler de açık bir şekilde YPJ'nin çocuk militan istismarını gözler önüne sermektedir (Anadolu Ajansı, 2018). Jandarma Genel Komutanlığı'nın teslim olan ve kaçan kadın örgüt üyelerinin ifadelerine yer verdiği raporda, "örgüte katılan kadınların çocuk denebilecek yaş grubu olan 10-18 yaş aralığında olduğu ve yüzde 52,8'inin ise ilkokul mezunu olduğu” belirtilmektedir (Anadolu Ajansı, 2021).

Çeşitli uluslararası kuruluşlar ve insan hakları örgütleri de YPJ’nin çocuk militan kullandığını çeşitli raporlarında teyit etmiştir. Örneğin, İnsan Hakları İzleme Örgütü yerel kaynaklara, uluslararası kuruluşların verilerine ve kaçırılan çocukların akrabalarına dayandırdığı 2015 tarihli raporunda YPJ'nin ve YPG'nin yapmamaya söz verdiği halde 18 ve hatta 15 yaş altındaki çocuklar1 militan olarak kullandığını belirtmektedir (Human Rights Watch, 2015). Birleşmiş Milletler Genel Sekreteri'nin Güvenlik Konseyi'ne sunduğu yıllık raporda, YPG/YPJ terör örgütü Suriye'deki silahlı çatışmalarda 15 yaşından küçük çocukları kullanan gruplar arasında zikredilmiştir (Security Council, 2015: 32). ABD Dışişleri Bakanlığı'nın 2016 yılında yayınladığı insan kaçakç1lığı raporunda da bu durum teyit edilmekte ve YPG/YPJ'nin on beş yaşından küçük çocukları silah altına aldığı, endoktrine ettiği ve çatışmalara soktuğu ifade edilmektedir (U.S. Department of State, 2016: 358).

YPJ’nin radikal feminist ideolojisini dayandırdığı Abdullah Öcalan tarafından dile getirilen "özgürleştirilen kadınlar” söylemi de gerçeği yansıtmamakta ve kadın teröristler "örgüt içerisinde kadın-erkek eşitliğine dayalı bir yapıdan ziyade, kadınların cinsel sömürüyle karşı karşıya kaldığı bir yapıyla muhatap" olmaktadır. Kadınlar örgüt içerisinde sık sık tecavüze ve cinsel istismara maruz kalmakta ve "seks kölesi" olarak kullanılmaktadır (Bayraklı ve Alkanat, 2021: 121-122 ve 143-144). Örgüt içerisindeki mağdurların ifadelerine yer verilen İçişleri Bakanlığı raporunda, başta ele başı Abdullah Öcalan olmak üzere, özellikle yönetici kadronun kadın militanları cinsel anlamda istismar ettiği ve bu istismarları eleştirenlerin ve karşı çıkanların infaz edildiği belirtilmektedir (İçişleri Bakanlığı, 2017a: 42-45). Kadın militanlar ayrıca intihar saldırıları gibi eylemlerde de sıklıkla kullanılmaktadır. Emniyet Genel Müdürlüğü Terörle Mücadele Dairesi Başkanlığı tarafından yayınlanan rapora göre PKK içerisindeki kadın teröristlerin oranı \%12 civarında olduğu halde, örgütün 1996-2010 yılları arasında düzenlediği intihar saldırılarının \%55'ini kadın militanlar gerçekleştirmiştir (Bayraklı ve Alkanat, 2021: 137-138).

YPJ/YPG terör örgütünün karıştığı suçlar sadece çocuk militanlarla veya kadınların istismarıyla sınırlı olmamıştır. Bu örgüt, pek çok uluslararası 
kurum ve kuruluşça da tespit edildiği üzere, savaş suçları ve insanlığa karşı suçlar işlemekte ve yaygın insan hakları ihlalleri yapmaktadır. PKK/YPG/ YPJ terör örgütü, kendisine muhalif gördüğü kişileri kaçırmakta, alıkoymakta veya infaz etmektedir. Ayrıca örgüt ele geçirdiği topraklarda yerel halkı mecburi göçe zorlamakta ve bazı yerleşim yerlerini tamamen tahrip etmektedir (İçişleri Bakanlığı, 2017b: 45-47).

Suriye İnsan Hakları Ağı'nın ifadesiyle, YPG kontrol ettiği bölgelerde terör ve aşırılık yanlıları ile mücadele bahanesiyle her türlü baskı, keyfi tutuklama, zorla kaybetme, adam kaçırma, yağmalama, etnik temizlik ve diğer yaygın insan hakları ihlallerini meşrulaştırmaya çalışmaktadır (Syrian Network for Human Rights, 2019). İnsan Hakları İzleme Örgütü, YPG/YPJ'nin siyasi uzantısı olan PYD’nin PKK'nın Suriye kolu olduğunu açıkça ifade ettiği 2014 tarihli raporunda, PYD kontrolündeki bölgelerde keyfi tutuklamalar, gözaltında taciz, yargı süreci ihlalleri, faili meçhul kayıplar ve cinayetler, muhalif göstericilerin öldürülmesi ve çocukların militan olarak kullanılması gibi suçların yaygın olarak işlendiğini belirtmektedir (Human Rights Watch, 2014). Uluslararası Af Örgütü ise “Gidecek Yerimiz Yok” başlıklı raporunda PYD’nin kontrol ettiği topraklarda yerel halkı zorla sürgün etme, sivillerin evleri yıkma, bazı durumlarda tüm köyleri yağmalama ve yakma gibi savaş suçları işlediğini vurgulamaktadır (Amnesty International, 2015).

\section{Ana Akım Batı Medyası Çerçevelemesinde Kahramanlaştırılan YPJ}

YPJ yukarıda değinilen suçları işleyen bir terör örgütü olduğu halde, ana akım Batı medyasındaki çerçevelemesinin nasıl olduğu incelendiğinde, karşımıza çok farklı bir tablo çıkmaktadır. YPJ'ye sempatisini ifade etmekten çekinmeyen Valentina Dean'ın bu örgüt hakkındaki 85 İngilizce haber metni üzerinde yaptığı metin analizi çalışması, en çok kullanılan kelimelerin "kadın”, "Kürt”, “savaşçı”, “dişi”, “mücadele” ve “IŞṠD” olduğunu göstermektedir (Dean, 2019: 19). YPJ ile ilgili ana akım Batı medyasındaki metinlere bakıld1ğında, hiçbirinde YPJ'nin bir terör örgütü olarak tanımlanmadığı görülmektedir. Hatta birkaç istisna dışında, YPJ'nin aksi yöndeki bütün açıklamalarına rağmen, bu örgütün PKK ile olan organik bağı görmezden gelinmektedir. Bu şekilde, Batılı ana aktörler tarafından bir terör örgütü olarak tanımlanan PKK'nın kötü sicili ile YPJ'nin bağlantısı Batılı kitlelerin gözünden kaçırılmaya çalışılmaktadır. Bununla birlikte, YPJ'nin işlediği yukarıda zikredilen suçlardan özellikle bahsedilmemektir. Böylelikle, kahramanlaştırıcı medya çerçevelemesi oluşturabilmenin önü açılmaktadır. 
YPG kendisini Batılı toplumlara seküler ve Batı yanlısı aktör olarak pazarlamak için özellikle Batılı tarzda giyinen ve klasik anlamda "Orta Doğulu" görünmeyen kadın figürünü kullanmaktadır. Bu anlamda YPJ militanları için özgür, eşit, eşitlikçi bir imaj çizmeye çalışmaktadır. Bu yüzden YPG'nin ezici çoğunluğu erkeklerden oluştuğu halde, bu örgütle ilgili medya yayınlarında genelde güzel göründüğü düşünülen kadın görselleri kullanılmaktadır. Böylelikle Batılı kitlelerin oryantalist ön yargıları üzerinden etkileyici bir kahraman figürü oluşturulmaya çalışılmaktadır (Alptekin ve Eliaçık, 2021).

Ana akım Batı medyasının kadın terör örgütü militanlarına dair kahramanlaştırma çabalarının kökenleri, Suriye İç Savaşı’nın da çok öncelerine dayanmaktadır. Örneğin, İngiliz The Guardian gazetesinin 2003 yılında yayınladığı kadın PKK militanlarıyla ilgili röportaj dosyasında militanlar şöyle tarif edilmektedir: “Kandil Dağı'nın yüksekliklerinde 5,000 silahlı kadın özgürlük ve cinsiyet eşitliği için savaşmaya hazır. Bazıları için şanlı özgürlük savaşçıları olmalarına rağmen, Batı için tehlikeli teröristler” Böylelikle, PKK'nın Batılı aktörler tarafından terör örgütü olarak tanımlanmasından yakınılmakta ve açıkça terör övgüsü yapılarak şöyle denilmektedir: “Türkiye’nin Güney Doğu'sundaki, Batı İran'daki, Kuzey Irak'taki, Doğu Suriye'deki ve diasporadaki pek çok Kürt için PKK özgürlük savaşçısıdır. Anavatanı için ve milleti olmayan bir halkın daha iyi haklara kavuşması için savaşmaktadır. PKK'nın yarıya yakını kadınlardan oluşmaktadır ve kadınların özgürlüğü amaçlarından biridir" (Burke, 2003).

İngilizce ana akım Batı medyasında YPJ'ye duyulan ilgi özellikle 2014 y1lında Ayn-el Arap'ta (Kobani) DEAŞ ile girdiği çatışma ile yoğunlaşmaya başlamıştır. Google arama motorunda İngilizce "Kurdish female fighters" (Kürt kadın savaşçılar) ifadesi için Suriye İç Savaşı'nın başlarındaki 33 aylık dönem kapsamında arama yapıldığında (15 Mart 2011 ila 31 Aralık 2013) toplam 5,230 sonuç çıkmaktadır. Bununla birlikte, aynı terim için 1 Ocak 2014 ila 1 Mayıs 2015 arasındaki 16 aylık dönem kapsamında arama yapıldığında 27,500 sonuç çıkmaktadır (Tank, 2017: 406). 2014'ün Aralık ayında Amerikan haber kanalı CNN, YPJ'yi "yılın en ilham verici kadınları" listesine dahil etmiştir. "Kadın savaşçılar yıllarca eğitim aldılar; ancak bu yıl Irak ve Suriye İslam Devleti’ne (IŞİD) karşı savaştaki cesur rolleriyle dikkat çekiyorlar” notuyla ödüllendirmiştir (CNN, 2014).

YPJ militanlarına dair övgüler genelde aile bağlantıları ve kişisel mağduriyet hikayeleri üzerinden yapılmaktadır (Tank, 2017: 410). Militanlar, kişisel hayat hikayeleri üzerinden okuyucunun gözünde insani özellikleriyle ön plana çıkarılmakta, mazlumken silahlanıp kendisinin, ailesinin, etnik grubunun 
ve hatta bütün insanlığın öcünü alan figürler olarak yüceltilmektedir. Örneğin, dört YPJ militanının detaylı hikayesine yer verilen “Çok Gururluyuz: Kobani’yi IŞİD’den Korurken Ölen Kadınlar” başlıklı makalede, militanlar aile üyelerinin dilinden anlatılmakta, kahraman birer "şehit" oldukları öne sürülmektedir. Kişisel travmalarına yer verilmekte ve silahlanıp YPJ’ye katılmalarının ne kadar makul ve hatta haklı gerekçelere dayandığına dair çerçeve çizilmektedir. Herkesin aslında onlara fedakarlıkları için minnettar olması gerektiği vurgulanmaktadır (Mahmood, 2015).

YPJ ile ilgili medya yayınlarında kullanılan görseller incelendiğinde, bunların çoğunlukla mutlu genç kadın görselleri olduğu görülmektedir. Bu kadınlar, uzun süren kanlı bir iç savaşın parçası olmak yerine, bu fotoğraflarda eğleniyor gibi görünmektedir. Böylelikle bu görseller oluşturulmak istenen pozitif imaja hizmet etmektedir. Zeliha Eliaçık'ın ifadesiyle, YPJ militanları Batı medyasında hayatlarından çok memnun olan kişiler olarak tasvir edilmektedir. Oysa gerçek bundan çok başkadır ve "hayatlarında sahip oldukları sadece savaş, kaos, kan, ölümdür.” Maruz kaldıkları istismarlar bu yayınlarda gizlenmektedir (Alptekin ve Eliaçık, 2021).

Batı medyasının YPJ hakkındaki çerçevelemesinin iki ana teması bulunmaktadır. Birinci ana tema YPJ-DEAŞ karşıtlığı üzerinden YPJ'nin kahramanlaştırılmasıdır. İkinci tema ise ütopik bir feminizm kurgusu üzerinden YPJ'nin yüceltilmesidir.

Birinci ana temada DEAŞ’ın temsil ettiği baskıcı, gerici, ataerkil ve İslamcı doğulu tip ile YPJ'nin temsil ettiği liberteryen, eşitlikçi, seküler ve demokratik Batılı tip denklemi kurulmaya çalışılmaktadır (Alptekin ve Eliaçık, 2021). Hiç kimse DEAŞ’ın terör örgütü olup olmadığı konusunda doğal olarak herhangi bir şüphe duymamaktadır. Ancak, YPG/YPJ söz konusu olduğunda Batı medyası bambaşka bir tavır sergilemektedir. Bu kapsamda, DEAŞ ile YPJ'nin ana akım Batı medyasındaki çerçevelemeleri arasında çok ciddi farklılıklar bulunmaktadır. Bu iki terör örgütü arasında karşıtlık tesis ederek, biri için olumsuz diğeri için olumlu kimlik inşaa edilmeye çalışıldığı açıkça görülmektedir. DEAŞ akla gelebilecek her tür kötülüğün kaynağı ve temsilcisi olarak sunulurken; YPG/YPJ'nin onun anti-tezi olduğu söylemi yürütülmektedir. YPJ DEAŞ’a karşı mücadele eden en başarılı aktör olarak sunulmakta ve böylelikle Batılı toplumların sempatisini kazanmaktadır.

YPJ'nin medya çerçevelemesinin ikinci ana teması feminizmdir. YPJ militanları yeni bir feminist otorite modeli olarak tasvir edilmektedir. YPJ'nin kontrolündeki bölge, yeni bir toplumsal cinsiyet ilişkileri anlayışıyla birlikte yeni yolların ve yeni siyasi ve ekonomik kalkınma biçimlerinin uygulanabileceği 
bir bölge olarak gösterilmektedir. Bazılarına göre YPJ “dünyanın gördüğü en feminist devrim"i gerçekleştirmektir ve bölgedeki cinsiyet ilişkilerine dair feodal anlayışı aşmak için bir fırsattır. Hatta "Rojava modeli” kadınların her geçen gün daha fazla sorun yaşadığı Batı dünyası için bile örnek olabilecek seviyededir (Ross, 2017). YPJ'ye katılan İngiliz vatandaşı Kimmie Taylor, The Independent'a verdiği röportajda "IŞİD’i kadın yoldaşlarımla birlikte bitirdik; şimdiki amacımız Orta Doğu’ya feminizmi yaymak” demektedir (Ervan, 2019). YPJ militanları, yeni bir kadın olma biçiminin inşasında önemli aktörler oldukları için, Ortadoğu'da yaygın olarak algılanan kadın modelinin antitezini temsil etmektedir.

\section{Moda ve Eğlence Yayınlarında YPJ}

Ana akım haber medyasının yanı sıra, normalde siyasi konulara girmeyen kadın dergileri bile bu medya çerçevelemesine dahil olmaktadır. Marie Claire, Esquire, Cosmopolitan, Elle ve Vogue gibi dergilerde çocuk militanların resimleri de kullanılarak YPJ kahramanlaştırılmaktadır. Örneğin, dünyanın en bilinen kadın dergilerinden olan Marie Claire'in 2014 Ekim sayısında “Bu olağanüstü Kadınlar IŞİD ile Savaşıyor. Şimdi Onların Kim Olduğunu Bilme Zamanı" başlıklı makalesinde açıkça 12-14 yaş aralığında olduğu gözüken çocuk askerlerin fotoğraflarını kullanmıştır. Daha sonra gelen tepkiler üzerine bu fotoğraflar kaldırılmış, fakat makale aynen korunmuştur (Griffin, 2014). Aynı yazar tarafından bu makalenin benzer versiyonları Esquire ve Cosmopolitan dergileri tarafından da yayınlanmıştır. Çocuk istismarı gibi konularda hassas olması beklenen bu mecralarda bile YPG övgüsünün çocuk militanların fotoğrafları eşliğinde yapılabilmesi durumun vahametini ortaya koymaktadır.

Bir başka örnekte, meşhur moda ve güzellik dergisi Elle'de yayınlanan makaleyle YPJ saflarına katılan ve Türkiye'nin Afrin operasyonunda etkisiz hale getirilen İngiliz vatandaşı Anna Campbell'ın hikayesi bir kahramanlık öyküsü olarak sunulmaktadır. “Çok idealist”, "kararlı” ve "cesaret sahibi bir feminist” olarak tanımlanan Campbell'ın daha iyi bir dünya inşa etmek için YPJ'ye katıldığı öne sürülmektedir (O’Malley, 2018). Yine aynı dergide yayınlanan bir başka makalede YPJ militanı olan Kanada vatandaşı Hanna Bohman Suriye'de gerçekleştirildiği iddia edilen “feminist devrim” in neferi olarak yüceltilmektedir. YPJ de "eşitlik ve demokrasi" için savaşan bir kahramanlar ordusu olarak takdim edilmektedir (O’Malley, 2017).

Okur kitlesi çoğunlukla genç kızlardan oluşan Teen Vogue gibi moda ve eğlence yayınları, YPJ militanlarını övdükleri yazılarda "kadın" yerine "kı" kelimesini tercih etmektedir. Örneğin, “IŞİD’in En Büyük Korkusu Kızlar 
Tarafından Öldürülmek" başlıklı makalede, İslam adına savaştığını düşünen DEAŞ’lıların bir Kürt kızı tarafından öldürülmeleri durumunda cennete gidemeyeceklerine inandığı öne sürülmektedir. Pek çok farklı yayında da ifade edilen bu iddia ile maskülen DEAŞ’lı ve feminen YPJ'li kimlik karşıtlığı keskin çizgilerle vurgulanmaktadır (Webster, 2015 ve Insider, 2015).

Bu terör örgütü hakkındaki "kahramanlaştırıcı" yayınların da etkisiyle YPJ militanı olmak o kadar "havalı" görülmeye başlamıştır ki 2014 yılında İsveç merkezli moda perakendecisi H\&M, YPJ savaşçılarının giysilerinden ilham alan bir koleksiyon yayınlamıştır. Böylelikle bir terörist grubu "masumlaştırma” girişimi konusunda yeni bir çığır açmıştır. Fakat YPJ taraftarları bu duruma tepki göstermiş ve bunun kendilerine yapılan bir saygısızlık olduğunu ifade etmiştir. Bunun üzerine ilgili şirket özür dilemek zorunda kalmış ve müşterilerinin görüşlerine değer verdiğini açıklamıştır (Wyke, 2014).

\section{Film ve Belgesellerde YPJ}

Yüceltici YPJ medya çerçevelemesinin haber metinlerinin çok ötesine geçtiği görülmektedir. YPJ övgüsü yapan çeşitli film ve belgeseller ödüllü yönetmenler tarafından hazırlanmakta; önemli uluslararası festivallerde gösterilmekte ve çeşitli uluslararası ödüller kazanmaktadır. Örneğin, “madem isteyen dışarıdan IŞİD’e katılabiliyor, neden ben de YPJ'ye katılmayayım diye düşündüm" diyen bir Kanadalı sivilin Suriye'ye gelmesini yücelten ve kahramanlık hikayesi olarak sunan Biz Kadınlardan Korkun (Fear Us Women) başlıklı ödüllü belgeselin tanıtımı şöyle başlamaktadır:

“Suriye'de kadınları özgürleştirmek ve IŞiD ile savaşmak için üç yılını Suriye'de geçiren Kanadalı bir sivilin, Hannah Bohman’ın hikayesi. Hannah'ın yürek parçalayıcı yolculuğu, IşiD ile mücadele etmekten daha büyük bir devrimi ortaya çıkarıyor: Cesur kadın askerlerin eşitlik için mücadelesi ve Ortadoğu'da kadınların özgürleştirilmesi. Tamamen kadınlardan oluşan bir Kürt ordusu olan YPJ'nin bir üyesi olarak Hannah, dünyanın en tehlikeli ülkelerinden birinde kurtuluş için savaşan cesur kadınlara içeriden bir bakış sağlıyor" (Darg, 2017).

Bir başka örnekte, gerçek hikayelere dayandığını söyleyen Silahlı Kız Kardeşler (Soeurs d'armes) başlıklı filmin yönetmeni yapımını şöyle tanıtmaktadır: “Ortadoğu'da savaşın harap ettiği bir ülkede genç bir Ezidi kaçırılır ve seks kölesi olarak satılır. Kürt direnişi kapsamında savaşan uluslararası bir kadın tugayına katılarak intikam almaya karar verir. Silah kullanmayı öğrenir ve direnişçilerin dayanışmasını görür. Kadınlar tarafından öldürülmekten korkan fanatik zalimleri cezalandırma olasılığını keşfeder. Bu film, kadınların ve Kürtlerin bizim adımıza kazandığı son Dünya Savaşı hakkındadır” (Fourest, 2019). 
Milan, Montreal ve Santa Barbara uluslararası film festivalleri gibi birçok organizasyonda ödül alan Gülistan: Güllerin Diyarı (Gulistan: Land of Roses) isimli belgesel gibi yapımlar, YPJ ismi yerine doğrudan PKK ismine atıfta bulunabilmektedir. PKK Kanada tarafından da bir terör örgütü olarak tanınmasına rağmen Kanada Milli Film Kurulu'nun da bu belgeselin yapımına ortak olması, terör övgüsü konusunda gelinen noktanın vahametini göstermektedir. Diğer yapımlarla benzer anlatıya sahip olan bu belgesel, YPJ militanlarını şöyle sunmaktadır: "Onlar, aynı zamanda aktif bir gerilla hareketi olan, PKK’nın silahlı kanadına bağlılar. Bu kadın savaşçıların görevi Irak ve Suriye'deki Kürt topraklarını savunmak, IŞİD’i mağlup etmek ve bu arada kadınların güçlendirilmesini sağlamak. Bu kadınlar cesurca barbarlığa karşı savaşlarını sürdürüyorlar. Bu belgesel ortak bir özgürlük vizyonuyla birleşen devrimci bir grup kadının feminist yüzünü ortaya koymaktadır” (Akyol, 2016).

Bu akımın son halkalarından biri de ABD Dışişleri Eski Bakanı Hillary Clinton ve kızının sahibi olduğu HiddenLight şirketi tarafından YPJ hakkında dizi çekileceğinin duyurulması olmuştur. Dizinin Gayle Tzemach Lemmon'un yüzlerce YPJ militanıyla yaptığı röportajlardan oluşan kitabının uyarlaması olacağı açıklanmıştır. Kobani'nin Kızları: Direnişin, Cesaretin ve Adaletin Hikayesi (The Daughters of Kobani: A Story of Rebellion, Courage, and Justice) başlıklı kitabı "adalet ve eşitlik için savaşan cesur, meydan okuyan kadınların olağanüstü bir anlatımı” olarak tanımlayan Clinton, bu diziyi ilham verici kahraman kadınların hikayesini dünyanın her yerinden izleyicilere ulaştıracak olmaktan dolayı büyük bir heyecan içerisinde olduğunu açıklamıştır (MacDonald, 2021). Halbuki ABD Dişişleri Bakanı olarak görev yaparken Suriye'nin PKK için bir güvenli alan olmaması konusunda Türkiye’nin kararlılığını paylaştığını söylemiş ve bu konuda Türkiye ile yakın çalışma sözü vermiştir. (Hürriyet Daily News, 2012).

\section{Sonuç}

YPJ çocukları militan olarak kullanma, kadınları cinsel yönden istismar etme, kendisine muhalif gördüğü kişileri kaçırma, alıkoyma ve infaz etme, ele geçirdiği topraklarda yerel halkı mecburi göçe zorlama, bazı yerleşim yerlerini tamamen tahrip etme ve keyfi tutuklamalar yapma gibi savaş suçları ve insanlığa karşı suçlar işlemekte ve yaygın insan hakları ihlalleri yapmaktadır. Oysa buna rağmen, Batı medyasında gayet olumlu bir şekilde tasvir edilmektedir. YPJ bir taraftan terör örgütü DEAŞ’ın antitezi olarak yüceltilmekte; diğer taraftan ütopik bir feminizm kurgusu üzerinden kahramanlaştırılmaktadır. 
Yüceltici YPJ medya çerçevelemesinin haber metinlerine hâkim olduğu görülmektedir. Ana akım haber medyasının yanı sıra, normalde siyasi konulara girmeyen kadın dergileri bile bu medya çerçevelemesine dahil olmaktadır. YPJ övgüsü yapan çeşitli film ve belgeseller ödüllü yönetmenler tarafından hazırlanmakta; önemli uluslararası festivallerde gösterilmekte ve çeşitli uluslararası ödüller kazanmaktadır.

Terör örgütlerinin ana akım medyadaki çerçevelemesinin aktörlerin bu örgütlere dair politikalarını şekillendirmede belirleyici bir etkisi bulunmaktadır. Hâkim medya söylemi bazı politikaları savunmayı imkânsız hale getirirken, bazı gayrimeşru yöntemleri meşruiyet dairesine sokmaktadır. Olumlu ve övgü dolu medya çerçevelemesi Batılı aktörlerin YPJ'yle ve onun ana çatısını oluşturan YPG terör örgütüyle iş birliği yapmasını meşrulaştırmıştır. Ayrıca, ana akım Batı medyasının bir terör örgütü olan YPJ ile ilgili medya çerçevelemesi, Batı toplumlarının farklı kesimlerini değişen derecelerde radikalleştirmiştir. Bazılarını sempatizan haline getirmiş; bazılarını siyasi ve hatta mali olarak destek vermeye teşvik etmiş; bazılarını ise doğrudan YPJ'ye gönüllü olarak katılmaya kadar götürmüştür.

\section{Kaynakça}

Akyol, Z. (Yönetmen). (2016). Gulistan, Land of Roses [Belgesel]. Kanada: Peripheria Productions.

Alptekin, H. and Eliaçık, Z. (2021, 3 February). Exploiting the Female Body: The YPG Case. Politics Today.

Amnesty International. (2015, October). 'We Had Nowhere Else to Go' Forced Displacement and Demolitions in Northern Syria. London.

Anadolu Ajansı. (2018, 7 Mart). Hafıza kartlarından YPG/PKK’nın 'çocuk savaşçıları’ çıktı.

Anadolu Ajansı. (2021, 2 Mayıs). Jandarmanın raporu, kandırılarak PKK’ya katılan kadınlara HDP'nin aracılık ettiğini ortaya koydu.

Argentieri, B. (2017, 18 August). Meet the female soldiers in Syria and Iraq fighting for gender equality as much as freedom, The Telegraph.

Avrupa Konseyi. (1950, 4 Kasım). İnsan Hakları ve Temel Özgürlüklerin Korunmasına İlişkin Sözleşme. Roma.

Bayraklı, E. ve Alkanat, A. (2021). PKK'da Kadın Teröristlerin Rolü ve Örgüt İçi Cinsel İstismar. Güvenlik Stratejileri Dergisi, 17(37),119-156.

Birleşmiş Milletler. (1948, 10 Aralık). İnsan Hakları Evrensel Beyannamesi. Paris.

Birleşmiş Milletler. (1998, 17 Temmuz). Uluslararası Ceza Mahkemesi'nin Roma Statüsü. Roma

Birleşmiş Milletler. (2000, 20 Mayıs). BM Çocuk Haklarına Dair Sözleşme'ye Ek Çocukların Silahlı Çatışmalara Dâhil Olmaları Konusundaki ihtiyari Protokol. New York. 
Burke, J. (2003, 11 May). Daughters of the revolution, The Guardian.

CNN. (2014, 22 December). The women of the year.

Darg, D. (Yönetmen). (2017). Fear Us Women [Belgesel]. ABD: RYOT Films.

Dean, V. (2019). Kurdish Female Fighters: The Western Depiction of YPJ Combatants in Rojava, Glocalism: Journal of Culture, Politics and Innovation, 1, 1-29,

Entman, R. (1993). Framing toward clarification of a fractured paradigm. Journal of Communication, 43(4), 51-58.

Ervan, A. (2019, 25 March). I eradicated Isis with my women comrades - now our aim is to spread feminism across the Middle East. The Independent.

Fourest, C. (2019). Soeurs d'armes [Sinema Filmi]. Fransa: Place du Marché Productions.

Griffin, E. (2014, 1 October). These Remarkable Women Are Fighting ISIS. It's Time You Know Who They Are. Marie Claire.

Hoffman, B. (2006). Inside Terrorism. New York: Columbia University Press.

Hürriyet Daily News. (2012, 11 August). Syria must not become a haven for PKK: Clinton.

Human Rights Watch. (2014, 19 June). Under Kurdish Rule: Abuses in PYD-run Enclaves of Syria. New York.

Human Rights Watch. (2015, 15 July). Syria: Kurdish Forces Violating Child Soldier Ban. New York.

Insider. (2015, 11 December). ISIS is afraid of girls. Erişim adresi: https://www.youtube.com/ watch?v=F_Bx20bYDCg

İçişleri Bakanlığı. (2017a, Şubat). PKK/KCK Terör Örgütünün Çocukları ve Kadınları İstismarı. Ankara.

İçişleri Bakanlığı. (2017b, Mayıs). PKK/KCK Terör Örgütünün Suriye Kolu: PYD-YPG. Ankara.

MacDonald, A. (2021, 26 January). Hillary Clinton set to produce TV show about female Kurdish fighters. Middle East Eye.

Mahmood, M. (2015, 30 January). We are so proud - the women who died defending Kobani against Isis, The Guardian.

O'Malley, K. (2017, 20 December). Meet The Canadian Who Fights ISIS Alongside 10,000 Women. Elle.

O’Malley, K. (2018, 19 March). Anna Campbell Becomes First British Woman to Be Killed Fighting With Kurdish YPJ Unit. Elle.

Reese, S. D. (2001). Prologue-Framing Public Life: A Bridging Model for Media Research. Stephen D. Reese, Oscar H. Gandy and August E. Grant (Eds). in Framing Public Life: Perspectives on Media and Our Understanding of the Social World (pp. 7-31). New Jersey: Lawrence Erlbaum Associates Inc.

Reuters. (2017, 23 October). YPG fighters credit Ocalan with Syria victory.

Ross, C. (2017, 24 July). The Most Feminist Revolution the World Has Ever Witnessed. Vice.

Schmid, A. P. (1989). Terrorism and the Media: The ethics of Publicity. Terrorism and Political Violence, 1(4), 539-565.

Security Council. (2015, 5 June). Children and armed conflict: Report of the Secretary-General. General Assembly. Sixty-ninth session. Agenda item 64. 
Spencer, A. (2012). Lessons Learnt: Terrorism and the Media. Arts and Humanities Research Council. Swindon.

Syrian Network for Human Rights. (2019, 10 September). Nearly 3,000 Individuals Are Still Detained or Forcibly Disappeared by Syrian Democratic Forces.

Tank, P. (2017). Kurdish Women in Rojava: From Resistance to Reconstruction. Die Welt Des Islams, 57, 404-428.

Tankard, J. (2001). The Empirical Approach to the Study of Media Framing. Stephen D. Reese, Oscar H. Gandy and August E. Grant (Eds). in Framing Public Life: Perspectives on Media and Our Understanding of the Social World (pp. 95-105). New Jersey: Lawrence Erlbaum Associates Inc.

Tankard, J., Hendrickson, L., Silberman, J., Bliss, K. and Ghanem, S. (1991). Media frames: Approaches to conceptualization and measurement. Paper presented to the Association for Education in Journalism and Mass Communication, Boston.

Thatcher, M. (1985, 15 July). Speech to American Bar Association. Erişim adresi: https:// www.margaretthatcher.org/document/106096

U.S. Central Command. (2014, 28 February). Ready for the fight. https://twitter.com/CENTCOM/status/836574056468082688. By popular demand, more photos of the female fighters. https://twitter.com/CENTCOM/status/836573860669571072

U.S. Department of State. (2016, June). Trafficking in Person Report. Washington.

van Dijk, Teun A. (1985). Structures of News in the Press. Teun A. van Dijk (Ed.). in Discourse and Communication (pp. 69-93). Berlin: Walter de Gruyter.

van Dijk, Teun A. (1995-a). Power and the News Media. David Paletz (Ed.). in Political Communication in Action: States, Institutions, Movements, Audiences (ss. 9-36). Cresskill, NJ: Hampton Press.

van Dijk, Teun A. (1995-b). The Mass Media Today: Discourses of Domination or Diversity? Javnost - The Public: Journal of the European Institute for Communication and Culture, 2(2), 27-45.

van Dijk, Teun A. (2017). How Globo media manipulated the impeachment of Brazilian President Dilma Rousseff. Discourse \& Communication, 11 (2), 199-229.

Webster, E. S. (2015, 14 December). ISIS's Biggest Fear Is Being Killed by Girls, Teen Vogue.

Woods, J. (2007). What We Talk about When We Talk about Terrorism: Elite Press Coverage of Terrorism Risk from 1997-2005. The Harvard International Journal of Press/Politics, 12(3), 3-20.

Wyke, T. (2014, 6 October). H\&M apologises after being accused of modelling $£ 15$ khaki outfit on uniform worn by Kurdish female fighters battling ISIS, Daily Mail.

Yanarışık, O. (2015). Turkey-EU Relations and the Representation of AK Party in the Western Political and Media Discourse (Unpublished PhD thesis). University of Warwick Department of Politics and International Studies, Coventry. 